\title{
A comparison of Microtops II and satellite ozone measurements in the period 2001-2011
}

\author{
J.L. Gómez-Amo a,b,*, V. Estellés ${ }^{a}$, A. di Sarra ${ }^{b}$, R. Pedrós ${ }^{a}$, D. Sferlazzo ${ }^{c}$, M.P. Utrillas ${ }^{\text {a }}$, \\ J.A. Martínez-Lozano ${ }^{a}$ \\ a Departament de Física de la Terra i Termodinàmica, University of Valencia, Spain \\ ${ }^{\mathrm{b}}$ Laboratory for Earth Observations and Analyses, ENEA, Rome, Italy \\ ${ }^{\mathrm{c}}$ Laboratory for Earth Observations and Analyses, ENEA, Lampedusa, Italy
}

\section{A R T I C L E I N F O}

\section{Article history:}

Received 22 May 2012

Received in revised form

26 December 2012

Accepted 31 December 2012

Available online 11 January 2013

Keywords:

Total ozone content

Microtops II

TOMS

OMI

GOME

GOME-2

\begin{abstract}
A B S T R A C T
Daily average total ozone Microtops measurements obtained during several campaigns conducted from 2001 to 2011 at latitudes from 31 to $68^{\circ} \mathrm{N}$ and in different seasons are compared with satellite observations. The Microtops ozone is derived using different wavelength combinations (Channel I, $305.5 / 312.5 \mathrm{~nm}$; Channel II, 312.5/320 nm; and Channel III, 305.5/312.5/320 nm). Satellite data from TOMS, OMI, GOME, and GOME-2 are used in the comparison. The three Microtops channels show a high correlation with the satellite retrievals. Channel I shows the best results and produces a mean bias deviation (MBD) less than 2.14\% with respect to TOMS, OMI and GOME. The MBD increases to 3\% in the comparison against GOME-2, due to the small number of available data. In addition, the total ozone content provided by Channel I displays the more stable behavior during the ten-year period. The Channel III total ozone shows MBD values smaller than those observed for Channel I. However the Channels II and III present a larger variability and show a larger spread of the data. Consequently, Channel I appears as the best option for long term measurements with Microtops.
\end{abstract}

(c) 2013 Elsevier Ltd. All rights reserved.

\section{Introduction}

Systematic remote sensing measurements of total ozone content (TOC) from satellite were started in 1970s. The different versions of the Total Ozone Mapping Spectrometer (TOMS) (2012) have been operational from 1978 to 2005 onboard four different satellites (NIMBUS7, Meteor3, ADEOS, and Earth Probe). TOMS was followed by the Ozone Monitoring Instrument (OMI) (Levelt et al., 2006), launched on the EOS/AURA satellite in 2004. Two versions of the Global Ozone Monitoring Experiment (GOME and GOME-2) (Valks et al., 2004) and the SCanning Imaging Absorption SpectroMeter for Atmospheric CHartographY (SCIAMACHY) (Eskes et al., 2005) instruments were launched by the European Space Agency on different satellites: GOME on the European Remote Sensing satellite (ERS-2), in 1995; SCHIAMACHY on ENVISat in 2002; GOME-2 on EUMETSAT Meteorological Operational Satellite (MetOp) in 2006.

Satellite observations require a thorough verification and groundtruthing. Ground based determinations by the Dobson (Dobson, 1931), and the automated Brewer (Brewer 1973) spectrophotometers

\footnotetext{
* Corresponding author at: Departament de Física de la Terra i Termodinàmica, University of Valencia, C/Dr. Moliner, 50, 46100 Burjassot, Spain.

Tel.: + 3496354 3255; fax: + 34963543385 .

E-mail address: jlgomeza@uv.es (J.L. Gómez-Amo).
}

are considered reference measurements of total ozone content. Dobson and Brewer ozone measurements agree within $1 \%$ when the major sources of discrepancy are properly accounted for Balis et al. (2007a). Typical deviations of satellite measurements with respect to Brewer and Dobson instruments are around 2\% (e.g. McPeters and Labow, 1996; Vanicek, 2006; Balis et al., 2007a, 2007b).

The Microtops II is a small size portable photometer that can be used as an alternative to measure total ozone content. It is adequate to be used in intensive field campaigns or in remote locations (e.g. Gómez-Amo et al., 2012a) as well as in permanent atmospheric stations. Its easy operation and short measurement time allow instantaneous ozone measurements even under partially cloudy skies (Köhler, 1999). The routine use of Microtops measurements can contribute to increase the spatial distribution of total ozone observations from the ground, including areas with poor satellite coverage.

Previous studies were devoted to describe the Microtops and test its performance (Morys et al., 2001), analyzing its advantages, limitations and uncertainties (Flynn et al., 1996; Labow et al., 1996; Köhler, 1999; Holdren et al., 2001) as well as the operational procedures to improve the data quality and its long term performance (Gómez-Amo et al., 2012a).

This work is focused on the comparison of Microtops II against satellite TOC measurements from different sensors (TOMS, OMI, GOME and GOME-2). Measurements from several campaigns 
covering the ten year period from 2001 to 2011 and a wide range of latitudes $\left(31-68^{\circ} \mathrm{N}\right)$ have been used for the analysis. This work is intended to test the capability of the same instrument to take accurate TOC measurements in different conditions. Previous studies comparing Microtops against satellite sensors are limited at a single location and a short period of time (e.g. Massen, 2003, 2005; Srivastava et al., 2008; Silva and Tomaz, 2012).

\section{Observations and data}

\subsection{Microtops observations}

Microtops measurements in several intensive campaigns at seven different sites from 2001 to 2011 , covering latitudes from 31 to $68^{\circ}$ of the Northern hemisphere, were used in this study. The measurements were carried out in four Spanish stations (Madrid, Valencia, Barrax, and El Arenosillo), an African site (Marrakech, in Morocco), and two other European stations (Sodankylä, in Finland, and Lampedusa in Italy). Only the observations in Madrid and Valencia stations were carried out in urban environments. The rest of the measurements were done in rural or marine areas, relatively far away from pollution sources. A detailed description of the sites and observations can be found in Gómez-Amo et al. (2012a) for the campaigns carried out in Madrid and El Arenosillo. The observation station at Valencia is described by Estellés et al. (2007). The area of experimentation at Barrax and the different campaigns which took place at this site are discussed in Martínez-Lozano et al. (2007) and Estellés et al. (2008). The description of the measurements in Sodankylä, Marrakech, and Lampedusa is given by Gómez-Amo et al. (2006, $2008,2012 a)$, respectively. The geographic coordinates of these stations, the Microtops measurement period as well as the number of days with cloud free conditions available for the comparison are shown in Table 1 .

The measurements have been done with the instrument \#3682 which is a second generation of Microtops II "ozone monitor". It is a portable photometer designed for a hand-held operation. It measures the direct solar irradiance in three UV bands using a collimator with $2.5^{\circ}$ field of view (FOV). A narrow-band interference filter and a photodiode are used for each band. These three UV filters centered at $(305.5,312.5,320.0 \mathrm{~nm})$ have a nominal full width at half maximum (FWHM) of $2.4 \pm 0.4 \mathrm{~nm}$. The water vapor content was derived from measurements in the $940 \mathrm{~nm}$ band, and the aerosol optical depth from observations at $1020 \mathrm{~nm}$. These two filters have a FWHM band pass of $10.0 \pm 1.5 \mathrm{~nm}$. The physical and operational characteristics of Microtops II are described in detail by Morys et al. (2001).
Three different ozone values are retrieved using the combination of the signals at 305.5 and $312.5 \mathrm{~nm}$ (Channel I), of the bands at 312.5 and $320.0 \mathrm{~nm}$ (Channel II), and of the three UV bands (Channel III). The description of the methodology used in the retrieval can be found in Gómez-Amo et al. (2012a).

\subsection{Microtops calibration and data quality}

The Microtops II (\#3682) was calibrated in 1997, 2002, and 2010. In a previous study the performance of the Microtops ozone measurements was verified against co-located Brewer measurements (Gómez-Amo et al., 2012a). Different approaches to check the calibration state and its degradation with time were adopted. The analyses show that a linear interpolation between the consecutive calibrations produces the best results, also during the years without calibrations, against the Brewers The same calibration strategy was adopted also in this study. In addition, the Microtops procedure to improve the data quality suggested by Gómez-Amo et al. (2012a) was also implemented, and only the series of three or five observations within 1 min which display standard deviation of the signals less than $2 \%$ and standard deviation of the AOD at $1020 \mathrm{~nm}$ less than 0.015 have been used (Gómez-Amo et al., 2012a).

A comparison of Microtops ozone with Brewer measurements applying these procedures shows that the root mean square deviation between Microtops and Brewer are 1,2 and 2\% for Channels I, II and III respectively (Gómez-Amo et al., 2012a).

The Microtops ozone did not show any dependency on the latitude in the comparison against the Brewer for any of the three channels. In addition, the Channel I was found the best option to monitor the TOC and only an airmass dependency was observed for airmasses larger than 2.6 (Gómez-Amo et al., 2012a). This airmass dependency was observed also for Channel III. Moreover, Channels II and III showed a large sensitivity on the time since the last calibration and a slight dependency on the aerosols.

\subsection{Satellite measurements}

Four different ozone satellite datasets have been used in this study. TOMS instrument onboard the NASA Earth-Probe platform has been used. TOMS is a nadir viewing instrument with a footprint of $39 \times 39 \mathrm{~km}^{2}$. The used ozone data are based on the TOMS V8 algorithm (Bhartia and Wellemeyer, 2002), which has been used to process data from a series of four TOMS instruments flown since November 1978 until December 2005. It uses 2 wavelengths for ozone retrieval (mainly 317.5 and $331.2 \mathrm{~nm}$ ), while the other 4 wavelengths (depending on the instrument) are used for

Table 1

Sites where the campaigns were carried out and its temporal coverage from 2001 to 2011 and the aerosol optical depth at $1020 \mathrm{~nm}$.

\begin{tabular}{|c|c|c|c|c|c|}
\hline \multirow[t]{2}{*}{ Site } & \multirow[t]{2}{*}{ Dates } & \multicolumn{3}{|c|}{ AOD at $1020 \mathrm{~nm}$} & \multirow[t]{2}{*}{$N$} \\
\hline & & Average & Minimum & Maximum & \\
\hline Madrid (Spain), $\left(40.45^{\circ} \mathrm{N}, 3.72^{\circ} \mathrm{W}, 685 \mathrm{~m}\right.$ a.s.l.) & December 2001 & $0.081 \pm 0.02$ & 0.047 & 0.101 & 5 \\
\hline Sodankylä (Finland), $\left(67.37^{\circ} \mathrm{N}, 26.63^{\circ} \mathrm{E}, 179 \mathrm{~m}\right.$ a.s.l.) & April-June 2002 & $0.082 \pm 0.02$ & 0.042 & 0.113 & 14 \\
\hline \multirow[t]{3}{*}{ Valencia (Spain), $\left(39.51^{\circ} \mathrm{N}, 0.42^{\circ} \mathrm{W}, 30 \mathrm{~m}\right.$ a.s.l.) } & May-September 2003 & $0.128 \pm 0.09$ & 0.043 & 0.504 & 84 \\
\hline & July-December 2004 & $0.153 \pm 0.19$ & 0.026 & 0.831 & 38 \\
\hline & January-June 2005 & $0.085 \pm 0.04$ & 0.031 & 0.207 & 20 \\
\hline Marrakech (Morocco), $\left(31.66^{\circ} \mathrm{N}, 7.61^{\circ} \mathrm{W}, 586 \mathrm{~m}\right.$ a.s.l.) & March 2003 & $0.251 \pm 0.21$ & 0.058 & 0.615 & 8 \\
\hline \multirow[t]{3}{*}{ Barrax (Spain), $\left(39.06^{\circ} \mathrm{N}, 2.10^{\circ} \mathrm{W}, 700 \mathrm{~m}\right.$ a.s.l.) } & July 2003 & $0.139 \pm 0.09$ & 0.086 & 0.280 & 5 \\
\hline & July 2004 & $0.120 \pm 0.03$ & 0.097 & 0.161 & 6 \\
\hline & June 2005 & $0.155 \pm 0.11$ & 0.015 & 0.327 & 7 \\
\hline El Arenosillo (Spain), $\left(37.1^{\circ} \mathrm{N}, 6.7^{\circ} \mathrm{W}, 10 \mathrm{~m}\right.$ a.s.l. $)$ & May 2004 & $0.072 \pm 0.03$ & 0.044 & 0.108 & 5 \\
\hline \multirow[t]{3}{*}{ Lampedusa (Italy), $\left(35.52^{\circ} \mathrm{N}, 12.63^{\circ} \mathrm{E}, 45 \mathrm{~m}\right.$ a.s.l.) } & April-May 2008 & $0.217 \pm 0.17$ & 0.060 & 0.524 & 8 \\
\hline & May 2009 & $0.206 \pm 0.13$ & 0.119 & 0.350 & 3 \\
\hline & April-September 2011 & $0.155 \pm 0.11$ & 0.042 & 0.598 & 75 \\
\hline
\end{tabular}

Note: The uncertainty assigned for each single measurement of AOD at $1020 \mathrm{~nm}$ is 0.015 (Ichoku et al., 2002). 
diagnostic and error corrections (Balis et al., 2007a). Starting from the middle of year 2000, TOMS data displayed significant errors attributed to an optical degradation in the instrument. An empirical correction was applied to the TOMS data based on validation against the TOC regional averages (McPeters et al., 2007); by applying this correction the accuracy of the TOMS retrievals has increased significantly (e.g. Antón et al., 2010a).

The OMI instrument is onboard the NASA EOS/AURA spacecraft from 2004. It is a nadir viewing spectrometer that measures solar reflected and backscattered light in a selected range of the UV and visible spectrum. The Aura satellite describes a sun-synchronous polar orbit and provides global daily coverage with a spatial resolution of $13 \times 24 \mathrm{~km}^{2}$ in nadir. Two products of total ozone content are derived: OMI-TOMS and OMI-DOAS. The OMI-TOMS ozone data uses the TOMS V8.5 algorithm. It introduces slight differences with respect to the V8 algorithm, mainly related to the cloud top pressures. This modification increases the accuracy of TOC values under cloudy conditions (Yang et al., 2008).The OMI-DOAS ozone product (Veefkind et al., 2006) is based on a DOAS (Differential Optical Absorption Spectroscopy) technique. The algorithm uses hyperspectral measurements in the wavelength range 331.1 to $336.6 \mathrm{~nm}$, to reduce errors due to aerosols, clouds, surface effects, and sulfur dioxide from volcanic eruptions. The validation of TOMS and OMI against ground-based Brewer has been studied on a global scale. The results report deviations smaller than 1\% for TOMS and OMI-TOMS and $2 \%$ for OMI-DOAS (Balis et al., 2007a).

GOME onboard of ERS-2 is an across-track nadir-viewing spectrometer which covers the $240-793 \mathrm{~nm}$ spectral range with resolution varying from 0.2 to $0.4 \mathrm{~nm}$. It has been operational from 1997 to July 2011 in a sun-synchronous polar orbit. The nominal footprint of the instrument is $320 \times 40 \mathrm{~km}^{2}$ and the global coverage is reached in three days. GOME-2 is an enhanced version of GOME/ERS-2, covering the same spectral range. It is operational since 2006 on board of MetOp satellite in a sun-synchronous orbit. GOME-2 has a daily global coverage with a spatial resolution of $80 \times 40 \mathrm{~km}^{2}$. The operational algorithm for the retrieval of total ozone column from GOME2/MetOp is the GOME-2 Data Processor Version 4.2 (GDP 4.2), which is based on the operational GDP 4.0 algorithm used for processing the GOME/ERS-2 data (Loyola et al., 2011). In the case of GOME the deviation from the Brewer observations falls between -1 and $+1.5 \%$ (Balis et al., 2007b).

\section{Methodology}

The comparison between Microtops II and satellite measurements has been done using the averages of Microtops observations made around the satellite overpass. Daily average values have been also used when Microtops measurements were not available during the overpass. In that cases, the average was performed over measurements made with airmasses smaller than 2.6; this limit is set to avoid deviations due to the Microtops ozone airmass dependency (Gómez-Amo et al., 2012a).

The agreement between the instruments has been evaluated using a linear regression analysis of each satellite retrieval versus the Microtops observations. In addition, the relative deviation (RDEV) was calculated, and the mean bias deviation (MBD), the mean absolute deviation (MAD), and the root mean square deviation (RMSD) were obtained using the following expressions:

$$
R D E V_{i}=100 \cdot \frac{m \text { Tops }_{i}-\text { satellite }_{i}}{m \text { Tops }},_{i}
$$

$M B D=\frac{1}{N} \cdot \sum_{i=1}^{N} R D E V_{i}$,
$M A D=\frac{1}{N} \cdot \sum_{i=1}^{N}\left|R D E V_{i}\right|$

where $m T O P S_{i}$ are the Microtops TOC measurements and satellite the satellite determinations. $N$ is the number of days used in the intercomparison. The standard deviation of the mean value is calculated for each statistical indicator.

\section{Results and discussion}

Microtops measurements during 250 days with clear sky conditions are available over the period 2001-2011 for the comparison. These measurements have been compared with TOMS, OMI, GOME and GOME-2, depending on the time period and the satellite coverage in the geographical location where each campaign was carried out. Therefore, TOMS measurements were used for the period 2001-2005; OMI measurements, which use both the DOAS and the TOMS algorithms, are used after 2005. The daily level 3 global gridded products, TOMSEPL3.008 from TOMS instrument, and OMTO3e.003 and OMDOASe.003 from OMI averaged to $\left(1^{\circ} \times 1^{\circ}\right)$ were used individually for the comparison. In addition, the data TOMSEPL3.008 and OMTO3e.003 were also analyzed together since the retrieval is based in the same V8 TOMS algorithm, even if the data come from different instruments (Fioletov et al., 2008). Therefore, using that combination the Microtops-TOMS comparison was extended to the whole period 2001-2011 and 234 data pairs were used. The Microtops-OMI comparison, for both OMI-DOAS and OMI-TOMS, is based on 129 valid data pairs. Data from GOME and GOME-2 processed using the GDP4.2 were used from 2001 to July 2011 for GOME, and for 2008-2011 for GOME-2. Due to their temporal coverage, only 105 and 77 data pairs were used for GOME and GOME-2, respectively.

The use of gridded data increases the number of points to be used in the comparison. This is advantageous since the Microtops measurements were not carried out continuously during the whole temporal period. In addition, the use of gridded data is preferred in order to avoid issues related to the differences in the characteristics of the individual instruments and measurements (FOV, solar zenith angle, etc...) and the data set to be compared is homogenized (Fioletov et al., 2008).

The use of daily average values may affect the results of the comparison, since the diurnal TOC variability may be not negligible in many situations (Antón et al., 2010b). That may be especially relevant in urban areas where also the Brewers show a daily variation up to $2 \%$ (Kerr and McElroy, 1995). However, only measurements at Madrid and Valencia stations were done in urban environments. In the rest of the campaigns, the measurements were carried out far from the anthropogenic influence. In addition, most of the Microtops TOC data were obtained in coincidence with the satellite overpass, and the daily averages were calculated over a limited range of airmasses, generally in the central part of the day. Therefore, the influence of the residual TOC daily variability present in the Microtops dataset is expected to negligibly affect the comparisons.

\subsection{Overview of the measurements period}

The time series of the Microtops and Satellite ozone measurements from 2001 to 2011 are shown in Fig. 1. The total ozone amount displays a wide range of values during the whole period due to the different geographical locations and seasons. The Microtops values range in the interval 246-389 DU. In general, the three Microtops ozone values are slightly larger than those observed from satellites, whose values fall within the range 235-384 DU. The average Microtops-satellite differences are smaller than $10 \mathrm{DU}$ for 


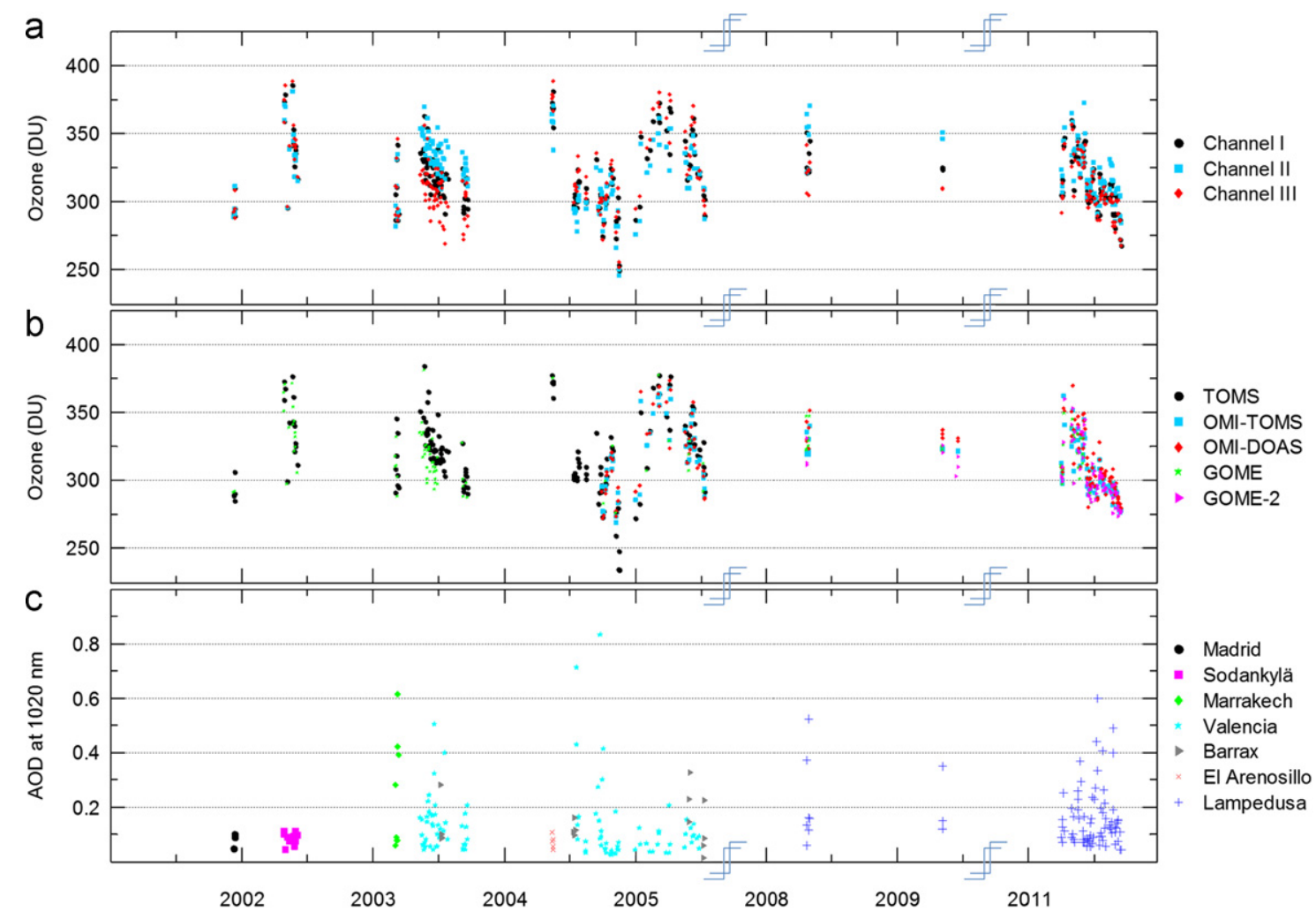

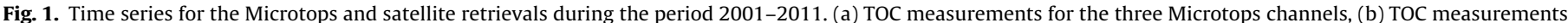
for the different satellite instruments and (c) AOD at $1020 \mathrm{~nm}$ measurements.

Channels I and III. Channel II shows differences larger than 10 DU with respect to all satellite measurements.

The differences among satellite ozone from different instruments do not exceed $14 \mathrm{DU}$ (Fig. 1b) and the MBD and MAD during the entire measurement period is smaller than 2 and $2.6 \%$, respectively. Although that results cannot be considered representative for a global satellite comparison, that is in agreement with Fioletov et al. (2008), who compared TOMS, OMI-TOMS, OMI-DOAS, and GOME measurements during the period 1978-2006 on a global scale, and found maximum differences of $3 \%$.

Fig. 1c shows the AOD at $1020 \mathrm{~nm}$ for the entire studied period. The AOD is measured by Microtops for the whole period, except for May-August 2003 at Valencia station, when the Microtops AOD was not available. During this period the Cimel AOD measurements at $1020 \mathrm{~nm}$ were used. The different colors indicate the different regions where each campaign was carried out. AOD displays a large range of values, from 0.015 to 0.831 ; the AOD variation is dependent on the considered campaign. Table 1 shows the AOD average ( \pm the standard deviation), as well as the minimum and maximum values measured during each campaign. Most of the values are smaller than 0.1 . Most of the values larger than 0.2 are found in the campaigns in Marrakech, Barrax, Valencia and Lampedusa, probably due to the dust events which frequently affect these regions. Some of these events were studied and well documented, by Gómez-Amo et al. (2008) for the Marrakech campaign, by Martínez-Lozano et al. (2007) and Estellés et al. (2008) at Barrax station, and finally by Meloni et al. (2012) and Gómez-Amo et al. (2012b) for the GAMARF campaign at Lampedusa.

\subsection{Microtops-satellite comparison}

Fig. 2(a, b and c) shows the time series of the relative deviations (RDEV) between the Microtops and the different satellite measurements during the whole time period. Channel I shows a limited RDEV range, within the interval $[-4.5,+7.9] \%$, with respect to all sensors for the whole period (Fig. 2a) and remains more stable among the years. Channels II and III show a larger variability than Channel I, RDEV ranges in the intervals [-6.1, $+11.5] \%$ for Channel II (Fig. 2b), and in the interval $[-8.7,+7.6] \%$ for Channel III (Fig. 2c). Since the airmass dependence of the Microtops ozone values has been shown to be negligible for airmasses $<2.6$, the differences observed in Fig. 2 may be ascribed to the own Microtops-satellite comparison.

A linear regression forced through the origin was calculated to analyze the agreement between Microtops and satellite ozone observations using the whole dataset. The linear regression coefficients and other statistical parameters are reported in Table 2 . The uncertainty assigned to the statistical parameters is the standard deviation of the mean value.

The TOC provided by the three Microtops channels is well correlated with all satellite measurements and shows correlation coefficients higher than $0.97,0.92$, and 0.94 for the Channels I, II, and III, respectively. Moreover, the slope is close to the unity in all cases. As indicated by the positive MBD, the three channels overestimate the satellite observations almost in all cases, except in the cases corresponding to the comparison of Channels I and III against TOMS, which are slightly negative. Differences among the three Microtops channels exist, since the distribution of the data around the one by one line varies depending on the considered satellite dataset (Fig. 3).

Channel I data show the best correlation with the satellite observations since the data are uniformly distributed along the one by one line in all cases. The agreement is better for the TOMS and OMI-DOAS datasets, for which the MBD values suggest an underestimate by $-0.16 \%$, and an overestimate by $0.75 \%$, respectively. RDEV for Channel I is larger in the cases of OMI-TOMS, GOME and GOME-2, with MBD up to $2.14,1.7$, and 3\%, respectively. In addition, 


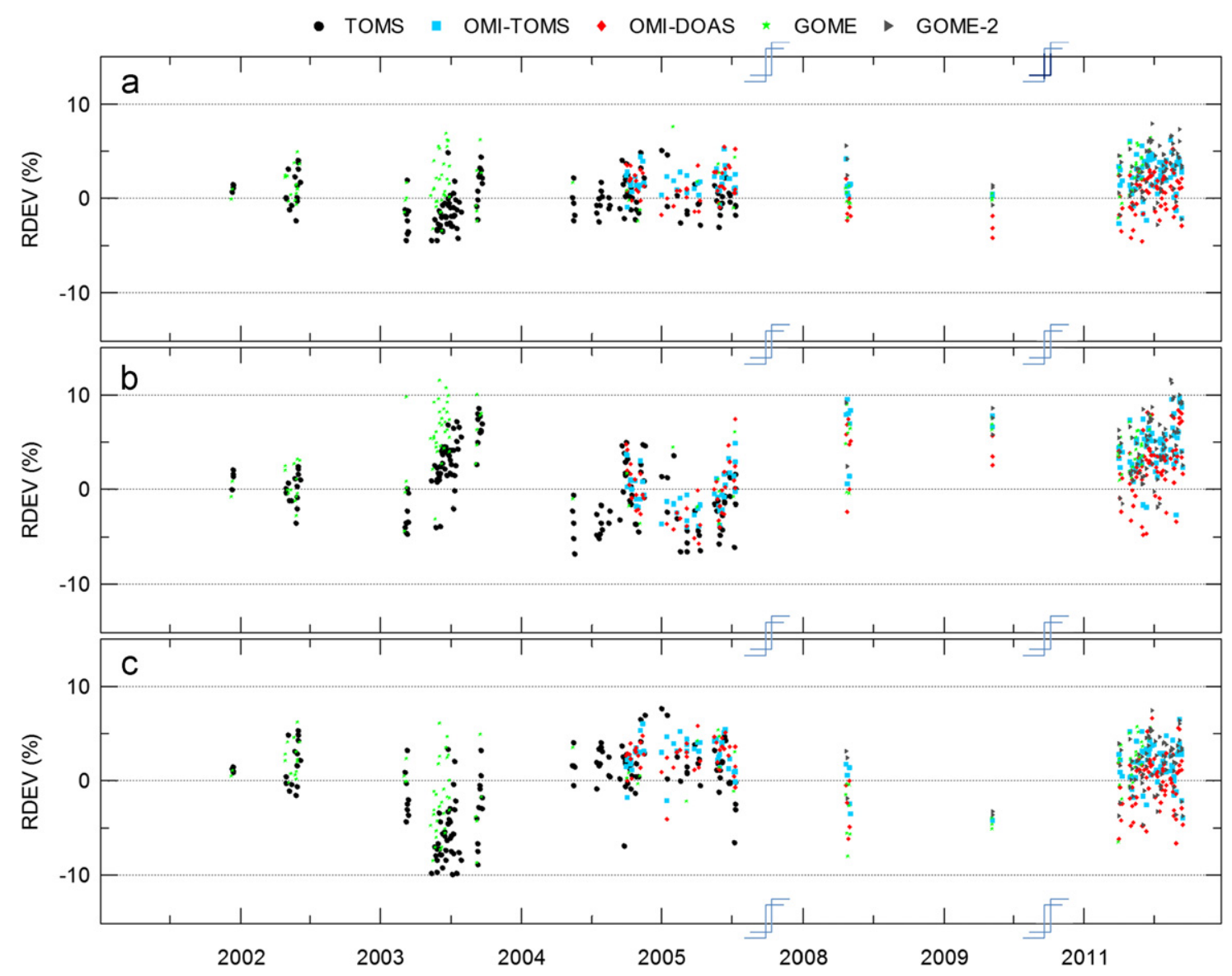

Fig. 2. Time series for the Microtops-satellite relative deviations RDEV. (a) Channel I, (b) Channel II and (c) Channel III.

Table 2

Parameters obtained from the statistical analysis of the Microtops-satellite deviations.

\begin{tabular}{|c|c|c|c|c|c|c|c|c|}
\hline Sensor & Slope & $R$ & MBD (\%) & MAD (\%) & RMSD (\%) & Median (\%) & Mode (\%) & $N$ \\
\hline \multicolumn{9}{|l|}{ Microtops Channel I } \\
\hline TOMS & $1.002 \pm 0.016$ & 0.98 & $-0.16 \pm 0.18$ & $1.78 \pm 0.10$ & 2.18 & -0.47 & -1 & 153 \\
\hline OMI-TOMS & $0.979 \pm 0.014$ & 0.99 & $2.14 \pm 0.15$ & $2.34 \pm 0.13$ & 2.73 & 2.15 & 1 & 129 \\
\hline OMI-DOAS & $0.993 \pm 0.016$ & 0.98 & $0.75 \pm 0.19$ & $1.81 \pm 0.11$ & 2.16 & 0.92 & 1 & 129 \\
\hline TOMS 2001-2011 & $0.993 \pm 0.016$ & 0.97 & $0.72 \pm 0.16$ & $2.14 \pm 0.09$ & 2.58 & 0.57 & 2 & 234 \\
\hline GOME & $0.98 \pm 0.02$ & 0.98 & $1.7 \pm 0.2$ & $2.29 \pm 0.19$ & 2.97 & 1.43 & 0 & 105 \\
\hline GOME-2 & $0.97 \pm 0.02$ & 0.98 & $3.0 \pm 0.3$ & $3.2 \pm 0.2$ & 3.77 & 3.13 & 3 & 77 \\
\hline \multicolumn{9}{|c|}{ Microtops Channel II } \\
\hline TOMS & $0.99 \pm 0.03$ & 0.95 & $0.55 \pm 0.3$ & $3.18 \pm 0.16$ & 3.76 & 1.01 & 2 & 153 \\
\hline OMI-TOMS & $0.97 \pm 0.03$ & 0.95 & $2.88 \pm 0.3$ & $3.7 \pm 0.2$ & 4.45 & 3.04 & 3 & 129 \\
\hline OMI-DOAS & $0.98 \pm 0.03$ & 0.95 & $1.61 \pm 0.3$ & $3.13 \pm 0.19$ & 3.76 & 1.82 & 3 & 129 \\
\hline TOMS 2001-2011 & $0.98 \pm 0.03$ & 0.92 & $2.04 \pm 0.3$ & $3.74 \pm 0.15$ & 4.37 & 2.51 & 3 & 234 \\
\hline GOME & $0.96 \pm 0.03$ & 0.95 & $3.9 \pm 0.4$ & $4.4 \pm 0.3$ & 5.26 & 4.4 & 5 & 105 \\
\hline GOME-2 & $0.95 \pm 0.03$ & 0.97 & $4.8 \pm 0.4$ & $4.9 \pm 0.3$ & 5.69 & 4.9 & 6 & 77 \\
\hline \multicolumn{9}{|c|}{ Microtops Channel III } \\
\hline TOMS & $1.01 \pm 0.03$ & 0.94 & $-0.76 \pm 0.3$ & $3.3 \pm 0.2$ & 4.24 & 0.29 & 2 & 153 \\
\hline OMI-TOMS & $0.980 \pm 0.017$ & 0.98 & $2.0 \pm 0.2$ & $2.61 \pm 0.13$ & 2.96 & 2.29 & 3 & 129 \\
\hline OMI-DOAS & $0.99 \pm 0.02$ & 0.97 & $0.6 \pm 0.3$ & $2.41 \pm 0.15$ & 2.91 & 1.12 & 1 & 129 \\
\hline TOMS 2001-2011 & $1.00 \pm 0.02$ & 0.94 & $0.0 \pm 0.2$ & $2.92 \pm 0.14$ & 3.62 & 0.91 & 3 & 234 \\
\hline GOME & $1.00 \pm 0.03$ & 0.95 & $0.0 \pm 0.4$ & $3.1 \pm 0.2$ & 3.71 & 0.5 & 0 & 105 \\
\hline GOME-2 & $0.98 \pm 0.02$ & 0.98 & $1.7 \pm 0.3$ & $2.78 \pm 0.18$ & 3.20 & 2.1 & 3 & 77 \\
\hline
\end{tabular}

these three comparisons displayed relative similar MBD and MAD values indicating that the data show a limited spread, lowest for GOME, intermediate for OMI-TOMS, and largest for GOME-2. However, the MBD and MAD observed for the comparison against TOMS and OMI differ, with a statistical spread of the data larger than $1 \%$ in both cases. The RMSD values are smaller than 3\%, except for the single case of GOME-2. The relatively large values of the statistical parameters obtained for GOME-2 are probably due to the limited number of data used, as it is also suggested by the larger uncertainties with respect to the other sensors. The biases observed for the Channel 


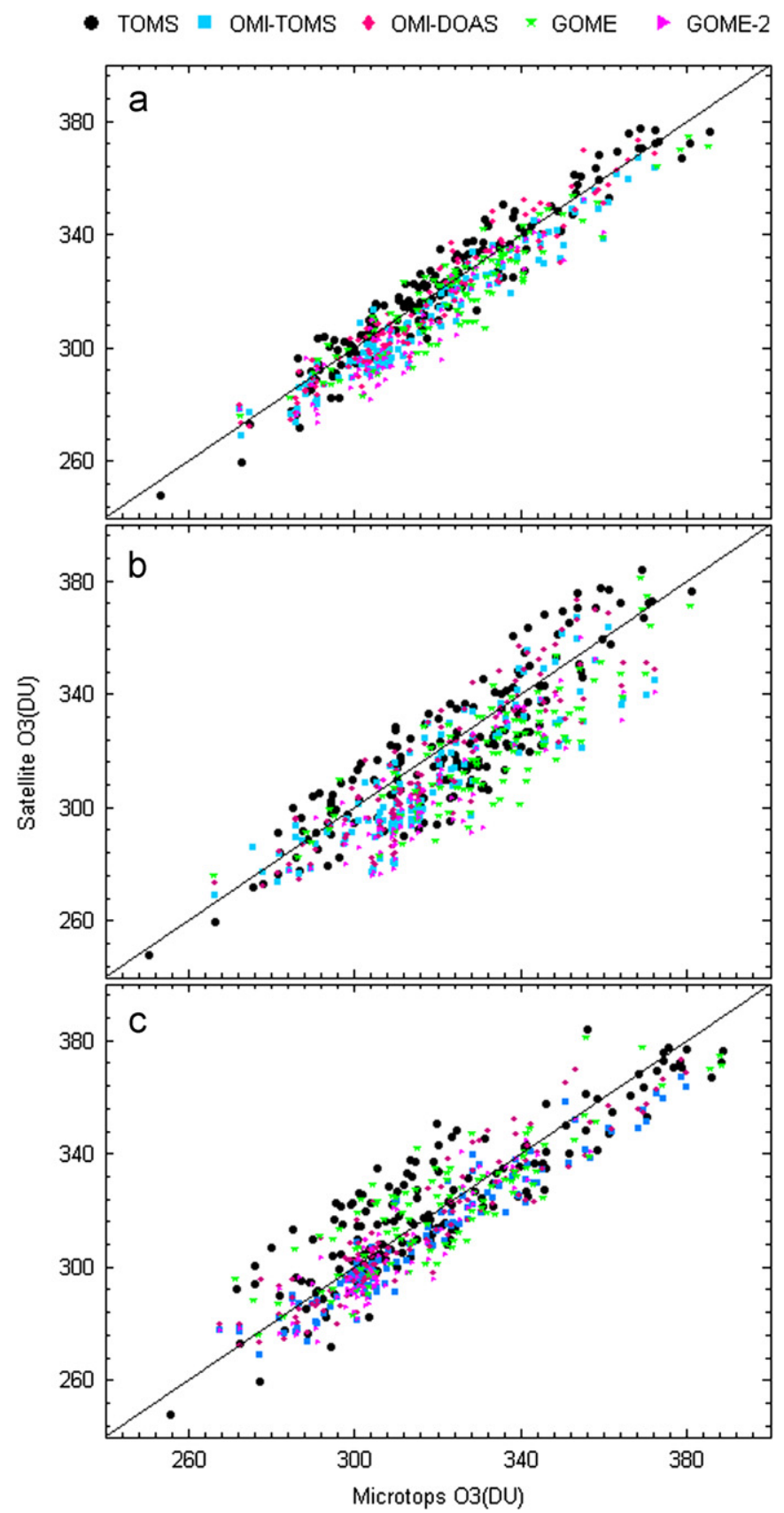

Fig. 3. Microtops-satellite scatter plots for the three channels. The black line is the one by one line. (a) Channel I, (b) Channel II and (c) Channel III.

I with respect to the different satellite measurements are similar to those observed in the Brewer-satellite comparisons taking into account the deviations reported by Antón et al. (2008, 2009a, 2009b), and Balis et al. (2007a, 2007b). Therefore, the ozone values provided by Channel I fall within the relative uncertainty assigned to satellite observations in all cases.

Despite the ozone values for Channels II and III are also well correlated with the satellite observations as is indicated by the linear regression parameters, both display very different statistical parameters for the comparison.

Channel II shows the largest deviation with respect to the satellite measurements. Only the comparison with TOMS shows a MBD smaller than $1 \%$. The rest of the cases show notable deviations, which are largest, $>3.9 \%$, for GOME and GOME-2. The MBD and MAD values for GOME and GOME-2 are similar, indicating that in most observations there is an overestimate by
Channel II. The scatter of the data is larger for the TOMS and OMI comparison and the differences between MBD and MAD are $>1.5 \%$. The larger deviation between Channel II and the satellite observations produces a large RMSD parameter, which is $>3.76 \%$ in all cases.

On the other hand, Channel III displays very low MBD values in comparison against all sensors. These are smaller than those observed for Channel I in almost all cases. However, the larger differences between MBD and MAD indicate large Channel IIIsatellite deviations. These differences exceed $2 \%$ in all cases, except for the GOME-2 comparison, which is around 1\%. Channel III displays RMSD values larger than $2.9 \%$ in all cases. In addition, both MAD and RMSD for Channel III are in all cases larger than those observed for Channel I, except for GOME-2.

The comparison using the combination of measurements from TOMS and OMI-TOMS for the entire period (TOMS 2001-2011) shows a behavior similar to that observed for OMI-DOAS for all channels. The Channels I and III data underestimate the TOMS measurements till 2005, while a compensation effect is produced by the overestimation of OMI-TOMS data after 2005.

The significance of the statistical analysis for Channels II and III is limited. That is due to the larger scattering observed in the comparison against all satellite observations (Fig. $2 b$ and c). It is also confirmed by the large differences between MBD and MAD and the increase of the standard deviation, assigned as the uncertainty to the MBD values, with respect to Channel I. Fig. 4 shows the frequency of occurrence of RDEV values for all the Microtops-satellite comparisons. The data display a sufficiently symmetrical distribution around the average value of RDEV for Channel I, as it is also confirmed by the similarity among MBD, the median, and the mode parameters (Table 2) for all cases. The median parameter is more representative than the mean value when the data are not symmetrically distributed, as it is the case for Channels II and III (Fig. 4). In these cases the median and the mode parameters display different values, and the statistical meaning of MBD and MAD is reduced.

The asymmetry in the RDEV distributions obtained for channels II and III is probably due to the different sensitivities to the calibration and aerosols observed for these channels with respect to Channel I. That is especially relevant in case of Channel II, which also showed a large spread in the comparison against Brewer ozone measurements for airmasses lower than 2.6 (Gómez-Amo et al., 2012a).

The poorest agreement is found in the Microtops-GOME-2 comparisons, especially for Channels I and II, and is attributed mainly to the relative low number of data used for the validation with respect to the other sensors.

Few studies are dedicated to comparisons between Microtops and satellite ozone measurements. Massen (2003, 2005) compare Microtops against Earth Probe TOMS, GOME, and SCHIAMACY using only Channel III, and concludes that the Microtops ozone is closer to the Brewer, with MBD in the range $[-10,+10] \mathrm{DU}$, than to satellite measurements. Srivastava et al. (2008) use only 9 days of measurements and concludes that Microtops values overestimate the Earth Probe TOMS by 9 DU. However, the relevance of these studies is limited because they use only few days for the comparison and only one of the Microtops channels.

Silva and Tomaz (2012) reports an average Microtops-OMI difference smaller than $2 \%$ using one year of measurements in an urban site in Brazil.

\section{Concluding remarks}

Ground based ozone measurements from Microtops II were compared with satellite observations from different instruments. 

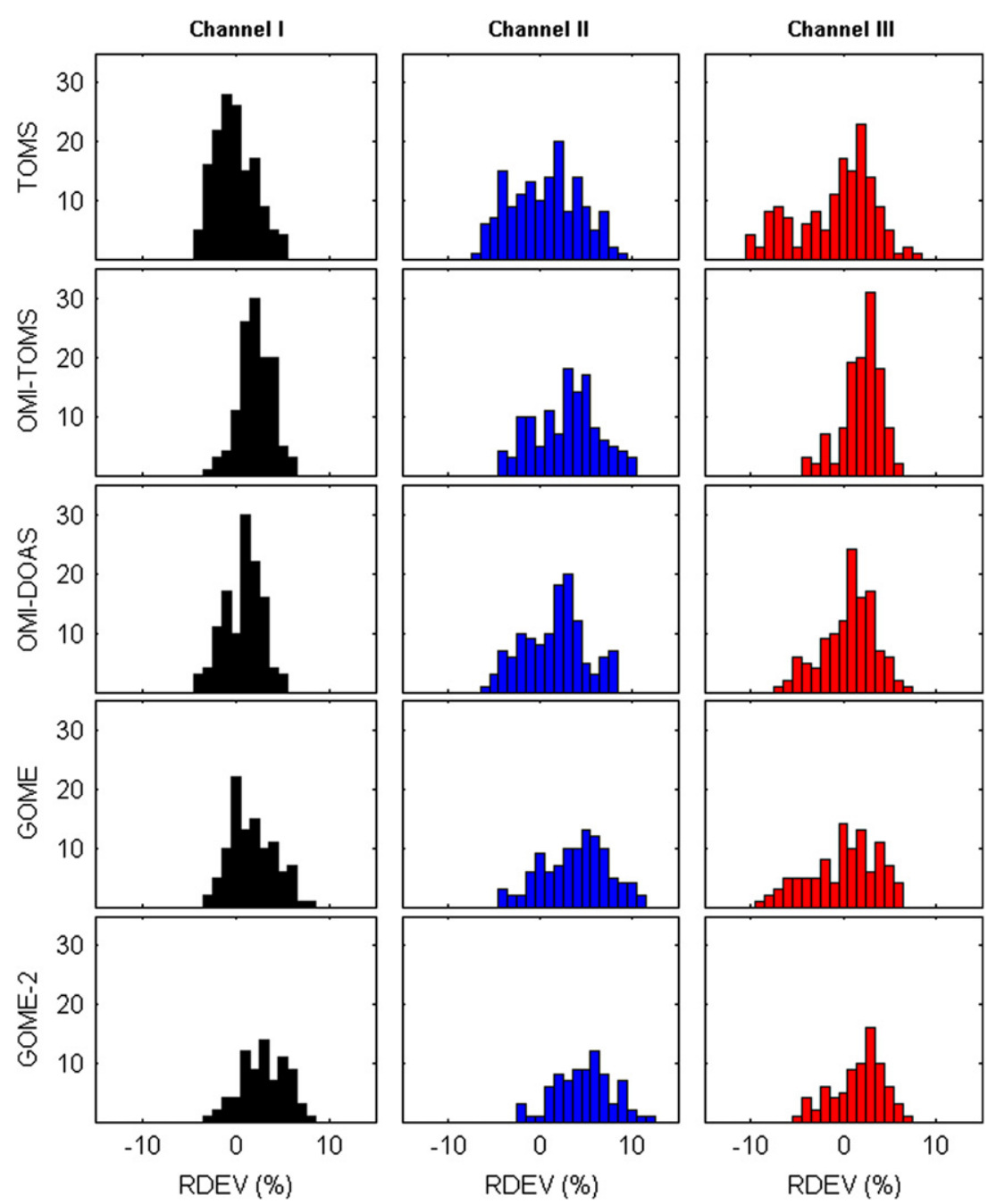

Fig. 4. Occurrence plots of the Microtops-satellite RDEV for the three channels.

Microtops observations carried out during a ten-year long period (2001-2011) at latitudes from 31 to $68^{\circ} \mathrm{N}$ are used in the comparison. Microtops measurements averaged around the satellite overpass time or daily mean values at airmasses lower than 2.6 (depending on the Microtops availability) are used in the validation against TOMS, OMI, GOME, and GOME-2. A linear regression and a statistical analysis were done to carry out the Microtops-satellite comparison. Since most of the measurements came from intensive and relatively short campaigns, the results obtained in this work cannot be taken as representative for the global agreement between satellite and Microtops instruments. However, it may contribute to test the ability of one single instrument to reproduce the ozone measurements in a large variety of atmospheric situations, locations and seasons.

The results show that the three Microtops retrievals are well correlated with the satellite measurements and a good agreement is found in all cases. The Microtops overestimates the satellite observations in almost all cases used for comparison, with the exception of the TOMS comparison against Channels I and III. Notable differences are observed among the channels.

The Channel I retrieval produces the best agreement, with a limited variability range of the deviations from the satellite measurements during the whole period. MBD is smaller than $2.14 \%$ for TOMS, OMI, and GOME, and reaches $3 \%$ in the comparison against GOME-2 due to the limited number of data used.

The biases displayed for Channel I are similar to those reported in the literature between the Brewer and satellite measurements in most of situations. Therefore, that indicates that the Microtops measurements provided by Channel I estimates the total ozone content within the satellite uncertainties ranges.

The ozone retrieval from the Channels II and III presents a larger variability. Channel II displays the largest biases against all satellite measurements. Conversely, Channel III produces the smallest MBD deviations, even lower than those shown by Channel I. However, the deviations of Channels II and III data do not show a homogeneous distribution and show large scattering in the comparison against all satellite observations. This spread is attributed to the sensitivities to calibration, airmass and aerosol variability observed for Channels II and III.

Thus, Channel I is the best option to monitor the total ozone content provided by satellite observations in all cases.

\section{Acknowledgments}

J.L. Gómez Amo holds a Postdoctoral Fellowship (EX20101192) funded by the Spanish Ministry of Education (MEC), and V. Estellés holds a Juan de la Cierva research contract (JCI-200904455) funded by the Spanish Ministry of Science and Innovation (MICINN). TOMS and OMI data used in this paper were produced with the Giovanni online data system, developed and maintained by the NASA GES DISC. We also acknowledge the TOMS and OMI mission scientists and associated NASA personnel for the production of the data used in this research effort. GOME and GOME-2 
products were generated at DLR under the auspices of the O3MSAF project funded by EUMETSAT and other European national contributions. This work was supported by the MICINN projects CGL2007-60648 and CGL2009-07790, and by the Valencian Autonomous Government through the Project PROMETEO/ 2010/064, and by the University of Valencia through the project UV-INV-AE11-41324.

\section{References}

Antón, M., Loyola, D., Navascúes, B., Valks, P., 2008. Comparison of GOME total ozone data with ground data from the Spanish Brewer spectroradiometers. Annals of Geophysics 26, 401-412.

Antón, M., Loyola, D., López, M., Vilaplana, J.M., Bañón, M., Zimmer, W., Serrano, A., 2009a. Comparison of GOME-2/MetOp total ozone data with Brewer spectroradiometer data over the Iberian Peninsula. Annals of Geophysics 27, 1377-1386.

Antón, M., López, M., Vilaplana, J.M., Kroon, M., McPeters, R., Bañon, M., Serrano, A., 2009b. Validation of OMI-TOMS and OMI-DOAS total ozone column using five Brewer spectroradiometers at the Iberian peninsula. Journal of Geophysical Research 114, D14307, http://dx.doi.org/10.1029/2009JD012003.

Antón, M., Koukouli, M.E., Kroon, M., McPeters, R.D., Labow, G.J., Balis, D., Serrano, A., 2010a. Global validation of empirically corrected EP-Total Ozone Mapping Spectrometer (TOMS) total ozone columns using Brewer and Dobson ground-based measurements. Journal of Geophysical Research 115, D19305, http://dx.doi.org/10.1029/2010JD014178.

Antón, M., López, M., Serrano, A., Bañón, M., García, J.A., 2010b. Diurnal variability of TOC over Madrid (Spain). Atmospheric Environment 44, 2793-2798.

Balis, D., Kroon, M., Koukouli, M.E., Brinksma, E.J., Labow, G., Veefkind, J.P., McPeters, R.D., 2007a. Ten years of GOME/ERS2 total ozone data-the new GOME data processor (GDP) version 4: 2. Ground-based validation and comparisons with TOMS V7/V8. Journal of Geophysical Research 112, D07307, http://dx.doi.org/10.1029/2005JD006376.

Balis, D., Kroon, M., Koukouli, M.E., Brinksma, E.J., Labow, G., Veefkind, J.P., McPeters, R.D., 2007b. Validation of Ozone Monitoring Instrument total ozone column measurements using Brewer and Dobson spectrophotometer groundbased observations. Journal of Geophysical Research 112 (D24S46), http://dx.d oi.org/10.1029/2007JD008796.

Bhartia, P.K., Wellemeyer, C., 2002. TOMS-V8 total O3 algorithm. In: Bhartia, P.K. (Ed.), OMI Algorithm Theoretical Basis Document, vol. II, OMI Ozone Products. NASA Goddard Space Flight Center, Greenbelt, MD, pp. 15-31, http://eospso.gsfc. nasa.gov/eos_homepage/for_scientists/atbd/index.php.

Brewer, A.W., 1973. A replacement for the Dobson spectrophotometer? Pure and Applied Geophysics 106-108, 919-927.

Dobson, G.M.B., 1931. A photoelectric spectrophotometer for measuring the amount of atmospheric ozone. Proceedings of the Royal Society 43, 324-339.

Eskes, H.J., van der, R.J., Brinksma, E.J., Veefkind, J.P., de Haan, J.F, Valks, P.J.M., 2005. Retrieval and validation of ozone columns derived from measurements of SCIAMACHY on Envisat. Atmospheric Chemistry and Physics 5 (4429-4475).

Estellés, V., Molero, F., Gómez-Amo, J.L., Fortea, J.C., Pedrós, R., Utrillas, M.P., Pujadas, M., Guanter, L., Martínez-Lozano, J.A., 2008. Characterization of the atmosphere during SEN2FLEX 2005 field campaign. Journal of Geophysical Research 113, D09205, http://dx.doi.org/10.1029/2007JD009237.

Estellés, V., Martínez-Lozano, J.A., Utrillas, M.P., Campanelli, M., 2007. Columnar aerosol properties in Valencia (Spain) by ground-based Sun photometry. Journal of Geophysical Research 112, D11201, http://dx.doi.org/10.1029/ 2006JD008167.

Fioletov, V.E., Labow, G., Evans, R., Hare, E.W., Kohler, U., McElroy, C.T., Miyagawa, K., Redondas, A., Savastiouk, V., Shalamyansky, A.M., Staehelin, J., Vanicek, K., Weber, M., 2008. Performance of the ground-based total ozone network assessed using satellite data. Journal of Geophysical Research 113, D14313. http://dx.doi.org/10.1029/2008JD009809.

Flynn, L.E., Labow, G.J., Beach, R.A., Rawlins, M.A., Flittner, D.E., 1996. Estimation of ozone with total ozone portable spectroradiometer instruments. I. Theoretical model and error analysis. Applied Optics 35 (30), 6076-6083.

Gómez-Amo, J.L., Martínez-Lozano, J.A., Utrillas, M.P., Pedrós, R., Estellés, V., 2006. Column-integrated aerosol optical properties in Sodankylä (Finland) during the Solar Induced Fluorescence Experiment (SIFLEX-2002). Journal of Geophysical Research 111, D05202, http://dx.doi.org/10.1029/2005JD006051.

Gómez-Amo, J.L., Estellés, V., Pedrós, R., Utrillas, M.P., Sobrino, J.A., MartínezLozano, J.A., 2008. Column aerosol characterization in a semi-arid region around Marrakech during the WATERMED 2003 campaign. International Journal of Remote Sensing 29 (17), 5013-5027.

Gómez-Amo, J.L., Estellés, V., di Sarra, A., Pedrós, R., Utrillas, M.P., MartínezLozano, J.A., González-Frias, C., Kyrö, E., Vilaplana, J.M., 2012a. Operational considerations to improve the performance of total ozone content by Microtops II measurements. Atmospheric Measurement Techniques 5 (1-11), 2012, http://dx.doi.org/10.5194/amt-5-1-2012.
Gómez-Amo, J.L., Meloni, D., di Sarra. A, Di Iorio, T., Junkermann, W., Estellés, V. Pace, G., Lorente,.J., 2012b. Vertical resolved aerosol characterization during the GAMARF campaign: aerosol size distribution and radiative properties. In: Proceedings of the International Radiation Symposium IRS, Berlin, Germany.

Holdren, D.H., Olsen, R.O., Schmidlin, F.J., 2001. Comparison of total ozone overburden from handheld photometers with the Wallops Island Dobson spectrophotometer. Geophysical Research Letters 28 (20), 3859-3862.

Ichoku, C., Levy, R., Kaufman, Y.J., Remer, L.A., Li, R.R., Martins, V.J., Holben, B.N., Abuhassan, N., Slutsker, I., Eck, T.F., Pietras, C., 2002. Analysis of the performance characteristics of the five-channel Microtops II Sun photometer for measuring aerosol optical thickness and precipitable water vapour. Journal of Geophysical Research 107 (13), 4179, http://dx.doi.org/10.1029/2001JD001302.

Kerr, J.B., McElroy, C.T., 1995. Total ozone measurements made with the Brewer ozone spectrophotometer during STOIC 1989. Journal of Geophysical Research 100 (D5), 9225-9230, http://dx.doi.org/10.1029/94JD02147.

Köhler, U., 1999. A comparison of the new filter ozonometer Microtops II with Dobson and Brewer spectrometers at Hohenpeissenberg. Geophysical Research Letters 26 (10), 1385-1388.

Labow, G.J., Flynn, L.E., Beach, R.A., Rawlins, M.A., Beach, R.A., Simmons, C.A Schubert, C.M., 1996. Estimation of ozone with total ozone portable spectroradiometer instruments. I. Theoretical model and error analysis. Applied Optics 35 (30), 6084-6089.

Levelt, P.F., Hilsenrath, E., Leppelmeier, G.W., Van den Oord, G.H.J., Bhartia, P.K., Tamminen, J., De Haan, J.F., Veefkind, J.P., 2006. The ozone monitoring instrument. IEEE Transactions on Geoscience and Remote Sensing 44, 1093-1101.

Loyola, D.G., et al., 2011. The GOME-2 total column ozone product: retrieval algorithm and ground-based validation. Journal of Geophysical Research 116, D07302, http://dx.doi.org/10.1029/2010JD014675.

Martínez-Lozano, JA., Estellés, V., Molero, F., Gómez-Amo, J.L., Utrillas, M.P. Pujadas, M., Fortea, J.C., Guanter, L., 2007. Atmospheric components determination from ground-level measurements during the Spectra Barax Campaigns (SPARC) field campaigns. IEEE Transactions on Geoscience and Remote Sensing 45 (9), 2778-2793.

Massen, F., 2003. A Comparison of the Total Ozone Measurements Done with the Microtops II Sun Photometer and the Uccle Brewer spectrophotometer. $\langle$ http://meteo.lcd.lu/papers/ozone/uccle/uccle_01a.html〉 (last access January, 2012).

Massen, F., 2005. A comparison of the 2005 Total Ozone Measurements Done with the Microtops II, Brewer, Toms and Sciamachy instruments. $<$ http://meteo.lcd. lu/papers/ozone/uccle/2005/uccle_2005.html > (last access January, 2012).

McPeters, R.D., Labow, G.J., 1996. An assessment of the accuracy of 14.5 years of Nimbus 7 TOMS version 7 ozone data by comparison with the Dobson network. Geophysical Research Letters 23 (25), 3695-3698.

McPeters, R., Taylor, S., Jaross, G., 2007, Empirically Corrected TOMS Earth Probe Data Set, 〈http://toms.gsfc.nasa.gov/news/Corrected_EP_TOMS_README pdf $>$ (last access October 2012).

Meloni, D., Di Iorio, T., di Sarra, A., Gómez-Amo, J.L., Junkermann, W., Monteleone, F., Pace, G., Piacentino, S., Sferlazzo, D.M., 2012. Vertical profiles of shortwave and longwave aerosol direct radiative forcing during GAMARF campaign at Lampedusa island, In: Proceedings of the International Radiation Symposium IRS, Berlin, Germany, 2012

Morys, M., Mims III, F.M., Hagerup, S., Anderson, S.E., Baker, A., Kia, J., Walkup, T., 2001. Design, calibration, and performance of Microtops II handheld ozone monitor and Sun photometer. Journal of Geophysical Research 106, $14,573-14,582$

Silva, A.A., Tomaz, L.M., 2012. Total ozone column measurements for an urban, tropical site in the Southern Hemisphere with a Microtops II. Journal of Atmospheric and Solar-Terrestrial Physics 77, 161-166, http://dx.doi.org/ 10.1016/j.jastp.2011.12.014.

Srivastava, A.K., Devara, P.C.S., Jaya Rao, Y., Bhavanikumar, Y., Rao, D.N., 2008 Aerosol optical depth, ozone and water vapor measurements over Gadanki, a tropical station in peninsular India. Aerosol and Air Quality Research 8 (4) 459-476.

TOMS, 2012, 〈http://toms.gsfc.nasa.gov/ozone/> (last access September, 2012).

Valks, P.J.M., de Haan, J.F., Veefkind, J.P., van Oss, R.F., Balis, D.S., 2004. TOGOMI: An Improved Total Ozone Retrieval Algorithm for GOME, XX Quadrennial Ozone Symposium. In: Zerefos, C.S. (Ed.), University of Athens, Athens, pp. 129-130 (1/6/2004-8/6/2004).

Vanicek, K., 2006. Differences between ground Dobson, Brewer and satellite TOMS-8, GOME-WFDOAS total ozone observations at Hradec Kralove, Czech. Atmospheric Chemistry and Physics 6, 5163-5171.

Veefkind, J.P., de Haan, J.F., Brinksma, E.J., Kroon, M., Levelt, P.F., 2006. Total ozone from the Ozone Monitoring Instrument (OMI) using the DOAS technique. IEEE Transactions on Geoscience and Remote Sensing 44 (5), 1239-1244, http://dx. doi.org/10.1109/TGRS.2006.871204.

Yang, K., Krotkov, N.A., Bhartia, P.K., Joiner, J., McPeters, R., Krueger, A.J., Vasilkov, A., Taylor, S., Haffner, D., Chiou, E., 2008. Satellite ozone retrieval with improved radiative cloud pressure. In: Proceedings of the Quadrennial Ozone Symposium, Tromso, Norway. 